\title{
Banking Competition and Stability: The Role of
}

\author{
Leverage*
}

\author{
Xavier Freixas $^{\dagger} \quad$ Kebin $\mathrm{Ma}^{\ddagger}$
}

August 20, 2014

\begin{abstract}
This paper reexamines the classical issue of the possible trade-offs between banking competition and financial stability by highlighting different types of risk and the role of leverage. By means of a simple model we show that competition can affect portfolio risk, insolvency risk, liquidity risk, and systemic risk differently. The effect depends crucially on banks' liability structure, on whether banks are financed by insured retail deposits or by uninsured wholesale debts, and on whether the indebtness is exogenous or endogenous. In particular we suggest that, while in a classical originate-to-hold banking industry competition might increase financial stability, the opposite can be true for an originate-to-distribute banking industry of a larger fraction of market short-term funding. This leads us to revisit the existing empirical literature using a more precise classification of risk. Our theoretical model therefore helps to clarify a number of apparently contradictory empirical results and proposes new ways to analyze the impact of banking competition on financial stability.
\end{abstract}

Keywords: Banking Competition, Financial Stability, Leverage

JEL Classification: G21, G28

*The authors have benefitted from the comments of Thorsten Beck, Elena Carletti, Fabio Castiglionesi, JeanEdouard Colliard, Marcella Lucchetta, Kalin Nikolov, Javier Suarez, Anjan Thakor, Wolf Wagner, Lucy White, and the participants to the American Finance Association meeting. Support from the FP7 Marie Curie Initial training Network is acknowledged by both authors. Xavier Freixas has benefitted from the support of Ministerio de Ciencia e Innovación, Generalitat de Catalunya, Barcelona GSE, Ministerio de Economía y Competitividad-ECO2011-25607; Banco de España-Excelencia en Educación-“Intermediación Financiera y Regulación” is gratefully acknowledged.

${ }^{\dagger}$ Universitat Pompeu Fabra, Barcelon GSE and CEPR. E-mail: xavier.freixas@upf.edu.

‡Warwick Business School, University of Warwick. E-mail:kebin.ma@wbs.ac.uk. 


\section{Introduction}

This paper reexamines the classical issue of the possible trade-offs between banking competition and financial stability by highlighting different types of risk and the role of leverage. By means of a simple model we show how competition affects portfolio risk, insolvency risk, liquidity risk and systemic risk differently. The relationships depend on banks' liability structure, on whether banks are financed by insured retail deposits or by uninsured wholesale debts, on whether bank leverage is exogenous or endogenous, and on the degree of competition in the banking industry. In particular, we show that, while in a classical retail deposit funded banking industry competition can increase financial stability, the opposite can be true for an originate-to-distribute banking structure with a large fraction of market short term funding.

Understanding the link between bank competition and financial stability is essential to the design of an efficient banking industry and its appropriate regulation. Because of the relevance of this topic, a large body of literature has been devoted to this issue, with important contributions from both theoretical and empirical perspectives. Yet, in spite of the critical importance of the subject and notwithstanding today's improved understanding of its complexity, there is no clear-cut consensus on the impact of competition on banks' risk taking and on the resulting overall financial stability.

On this issue, two main theoretical modeling approaches contend: the charter value view and the risk shifting view. The charter value theory, first put forward by Keeley (1990), assumes that banks choose their level of risk and argues that less competition makes banks more cautious in their investment decisions, since in case of bankruptcy they will lose the present value of their future rents generated by their market power. Instead, proponents of the risk shifting hypothesis, which originated with Boyd and De Nicolo (2005), postulate that risks result from the borrowing firms' decisions and point out that higher interest rates will lead firms to take more risk and therefore will increase the riskiness of the banks' portfolio of loans.

The theoretical debate cannot be solved by resorting to empirical evidence, which is oftentimes equally ambiguous and contradictory. ${ }^{1}$ Part of the ambiguity stems from the diversity of "financial stability" measurements. Indeed, bank risk has multiple dimensions, ranging from portfolio risk, to insolvency, illiquidity, and systemic risk. Because competition may affect different types of risk differently, there is no guarantee that papers that examine different

\footnotetext{
${ }^{1}$ See Beck, Jonghe, and Schepens (2011), who show that the relationship between competition and financial stability is ambiguous and displays considerable cross-country variation.
} 
risk measurements can find the same relationship between competition and financial stability. ${ }^{2}$ Therefore, we believe that a first requirement to analyze the competition-stability link is to build a model that encompasses different types of banking risks.

A second requirement is to consider the endogeneity of bank leverage, a point the literature has largely ignored. ${ }^{3}$ We emphasize that when competition affects the riskiness of bank loans, banks react to the change of risk by actively adjusting their leverage: For instance, safer loan portfolios can lead banks to take on more debt. Consequently, the insolvency risk of banks is not necessarily reduced. Furthermore, as banks adjust their leverage, all other bank risks, such as funding liquidity risk and systemic risk, are also affected. We believe that bank leverage constitutes a central hub that connects all types of banking risk and plays a key role in the analysis of the impact of competition on financial stability. Therefore, we build a model wehere bank leverage and risks are jointly determined by the optimization behavior of banks. Depending on the characteristics of the banking industry, a diverse range of predictions can rise. We believe this can help to reconcile with the empirical literature.

Our approach builds on a large body of literature on banking competition that starts with the seminal paper of Keeley (1990). As mentioned before, Boyd and De Nicolo (2005) rightly point out that the intrinsic countervailing force of firms' risk-shifting can make the relationship between competition and financial stability ambiguous. Martinez-Miera and Repullo (2010) further refine Boyd and De Nicolo's argument by showing that the low profit resulting from competition reduces banks'buffer against loan losses and can, therefore, jeopardize financial stability. Wagner (2009) considers both banks' and entrepreneurs' incentives to take risk on the portfolio side: Once entrepreneurs and banks move sequentially, the overall effect coincides with the charter value hypothesis. The fact that all these contributions focus solely on insolvency risk and take the simplifying assumption of exogenous leverage has been one of the main motivations for our paper. In this aspect, our paper is also related to Allen, Carletti, and Marquez (2009). The authors study banks' leverage in a competitive environmentshow and suggest that as competition reduces charter values, banks' incentives to monitor borrowers are reduced. In equilibrium, banks have to hold more capital to maintain proper incentives to monitor.

Because our objective is to explore the impact of competition on the different types of risk, our starting point has to be the microfoundations of borrowing firms' risk taking. Following

\footnotetext{
${ }^{2}$ Table 3 offers a synthetic survey of the different choices in the measures of competition and risk in the empirical contributions to the analysis of the competition-financial stability link.

${ }^{3}$ For example, Boyd and De Nicolo (2005) considers banks solely financed by debt. Martinez-Miera and Repullo (2010) assume the cost of equity to be independent of banks' risk.
} 
Boyd and De Nicolo (2005) and Martinez-Miera and Repullo (2010), we assume that firms' investment decisions are subject to moral hazard, so that a higher interest rate leads them to take riskier investment projects. Consequently, greater banking competition decreases portfolio risk but also reduces the banks' profit, which serves as a buffer against loan losses. On top of portfolio and insolvency risk, funding liquidity risk is then introduced through a global games approach. Using this framework, we study the impact of banks' competition on financial stability, both when bank leverage is exogenous and when it is endogenous.

Our main result is that the relationship between insolvency risk and banking competition crucially depends on the degree of banks' market power and their liability structure. The use of a specific model allows us to solve the model analytically and show that the risk shifting hypothesis is satisfied for a low level of insured deposits and high levels of market power while the charter value is correct in the opposite case. So the impact of banking competition on financial stability could be the opposite in a classical originate-to-hold banking industry and in an originate-to-distribute one. This result can be helpful in understanding the apparent contradictions in the empirical results; it is also relevant to test the impact of banking competition as it predicts that the results should vary depending on the characteristics of the banking industry.

In addition, our analysis of the different types of risks allow us to establish the impact of increased banking competition on each type of risk. First, when leverage is exogenous, which can be interpreted as capital requirements being binding, competition will always increase liquidity risk, because it reduces the banks' profits which can provides a buffer against liquidation losses. If instead, leverage is endogenous, it presents a countervailing force to portfolio risk, moving always in the opposite direction, because when the portfolio of assets becomes safer the bank will increase its leverage and its solvency and liquidity risks and conversely ${ }^{4}$. Nevertheless, the total credit risk of a bank, defined as the sum of solvency risk plus funding liquidity risk is dominated by the impact of competition on insolvency risk. We also extend the model to incorporate systemic risk and find the results to be robust: although the overall risk is higher, the impact of competition on financial stability still depends upon de degree of banks' market power and their liability structure.

The paper proceeds as follows. Section 2 lays out the model. Section 3 establishes the benchmark case, exploring how insolvency and liquidity risks are affected by banking com-

\footnotetext{
${ }^{4}$ This is clearly illustrated in the extreme case where a bank's strategy is to maintain a given insolvency risk, which is in line with the idea of "economic capital". In this case, any changes in portfolio risk are exactly offset by the bank's leverage adjustment.
} 
petition under the assumption of exogenous leverage. In section 4, we determine endogenous bank leverage and analyze its impacts on banks' insolvency and illiquidity. The results contrast with those under exogenous leverage. Section 6 extends the baseline model to study systemic risk and financial contagion. We devote section 6 to the empirical literature, reinterpreting the empirical findings with the refined definition of "financial stability" and forming new testable hypotheses. Relevant policy implications are discussed in section 7. Section 8 concludes.

\section{Model Setup}

\subsection{Portfolio risk and competition}

We consider a one-good, three-date $(t=0,1,2)$ economy where all agents are assumed to be risk neutral. There are three types of active agents: entrepreneurs, banks, and banks' wholesale financiers; and one type of purely passive agents: retail depositors. There are a continuum of entrepreneurs. They are penniless but have access to long-term, productive, but potentially risky projects. Each project requires one unit of initial investment and takes two periods to fruitify. It yields a gross return of $x>1$ if succeeds, and 0 if fails. Projects are subject to moral hazard: Each entrepreneur chooses privately a probability of success $P \in[0,1]$ in order to maximize his expected utility.

$$
E(U)=P(x-r)-\frac{P^{2}}{2 b}
$$

Here $r \in(1, x)$ is the gross loan rate charged by banks, and $P^{2} / 2 b$ denotes the disutility for exerting efforts. $b \in(0, B]$ represents an entrepreneur's type, with a higher $b$ implying a better type and lower marginal cost of effort. An entrepreneur's type is private information, in particular, unknown to banks. Banks hold a prior belief that $b$ is uniformly distributed in interval $[0, B]$. Entrepreneurs' reservation utility is normalized to zero.

Because idiosyncratic risk diminishes in a bank's diversified portfolio of loans, we dispense with modeling this type of risk, and focus instead on a non-diversifiable bank-level risk that affects the whole portfolio. We assumet that whether a project succeeds or not is jointly affected by an entrepreneur's choice $P$ and a bank-level risk factor $z$. The risk factor $z$ follows a standard normal distribution. Its realization is identical for all loans in a bank's portfolio, but can vary across banks. Following Vasicek (2002) and Martinez-Miera and Repullo (2010), we assume 
that the failure of a project is represented by a latent random variable $y$. When $y<0$, a project fails. The latent variable $y$ takes the following form

$$
y=-\Phi^{-1}(1-P)+z
$$

where $\Phi$ denotes the cumulative densitfy function of standard normal distribution. Thus a project defaults either because of an entrepreneur's moral hazard (a low $P$ ) or an unfortunate risk realization (a low $z$ ) that affects the bank's whole portfolio. For the sake of consistency, note that the probability of success $P$ is given by:

$$
\operatorname{Prob}(y \geq 0)=1-\operatorname{Prob}(y<0)=1-\operatorname{Prob}\left(z<\Phi^{-1}(1-P)\right)=1-\Phi\left(\Phi^{-1}(1-P)\right)=P .
$$

The modeling complexity is necessary to analyze banks' leverage. For leverage to play any role, there must be imperfect correlation for loan defaults. ${ }^{5}$ In the current setup, the bank-level risk factor $z$ generates correlated loan defaults, and the entrepreneur heterogeneity makes the correlation imperfect.

Banks are assumed to invest in a continuum of projects. We further assume the loan market is fully covered and all types of entrepreneurs are financed. The loan portfolio generates a random cash flow that we denote by $\theta$.

In order to focus on bank leverage and risk, we dispense with the specific modeling of loan market competition and consider the loan rate $r$ as a sufficient statistic for the degree of competition. With lower $r$ associated greater competition, our setup captures the driving force for risk reduction in Boyd and De Nicolo (2005) and is consistent with mainstream competition models that predict competition leading to lower spreads. ${ }^{6}$ The assumption also fits empirical literature, which finds low interest margins associated with lower market concentration, Degryse, Kim, and Ongena (2009).

\footnotetext{
${ }^{5}$ Under the simplifying assumptions of either zero or perfect correlation, a bank's capital level cannot affect its insolvency risk. In the first case, the law of large numbers leads to zero risk for a well diversified portfolio, and banks do not need hold any capital. In the second case, once the correlated defaults happen, any capital level lower than $100 \%$ is insufficient to prevent a bank failure.

${ }^{6}$ The opposite relationship may be obtained in models based on Broecker (1990) where an increase in the number of banks raises the probability for a bad borrower to get funded in equilibrium, which implies an increase in the equilibrium interest rate.
} 


\subsection{Bank funding and liquidity risk}

Each bank holds a unit portfolio of loans, ${ }^{7}$ and finances it with a mixture of debt and equity. At $t=0$, a bank raises $V_{F}$ from insured retail depositors, $V_{D}$ from short-term wholesale creditors, and the rest, $V_{E}=1-V_{D}-V_{F}$, from equity holders. Because insured retail depositors are insensitive to banks' risk and play a purely passive role, we assume that their supply of fund is inelastic and fixed, $V_{F}=F$. We also assume that the financial safety net of deposit insurance is offered to banks at no cost. ${ }^{8}$

The wholesale debts are assumed to be raised in a competitive market where investors are risk neutral and require a market interest rate that is normalized to zero. Each bank's debt is jointly financed by a continuum of creditors. The debts are demandable, risky, and promise a face value $D$ at $t=2$. Their short-term nature allows wholesale creditors to withdraw early at $t=1$, before banks' risky investment matures. Provided that a bank does not fail at $t=1$, a creditor receives $q D$ by running on the bank. Here, $1-q \in(0,1)$ represents an early withdrawal penalty. Alternatively, the debt contract can be viewed as promising an interest rate $q D / V_{D}$ at time $t=1$ and $D / V_{D}$ at time $t=2$. For simplicity, we assume that the bankruptcy cost is sufficiently high such that once bankruptcy happens, the wholesale creditors get zero payoffs and only a senior deposit insurance company gets the residual cash flow.

We follow the literature of global games and model bank runs as a non-cooperative game of incomplete information. We assume that at $t=1$ each wholesale creditor privately observes a noisy signal $s_{i}=\theta+\epsilon_{i}$, where $\epsilon_{i}$ is pure noise that follows a zero-mean continuous distribution on a small interval. Based on the signal, the wholesale creditors play a bank-run game. Each of them has two actions: to wait until maturity or to withdraw early. A creditor who chooses to withdraw early will receive nothing if the bank fails at $t=1$, and $q D$ if the bank does not fail on the intermediate date. If the bank is only able to pay early withdrawals at $t=1$ but goes bankrupt at $t=2$, creditors who choose to wait will receive nothing. If the bank does not fail at $t=2$, depositors who choose to wait receive the promised repayment $D$. Once a bank's cash flow is insufficient to repay its debt, it declares bankruptcy and incurs a bankruptcy cost.

\footnotetext{
${ }^{7}$ The assumption that banks hold only loans but no cash is obviously meant to simplify the model. But to allow for endogenous cash holding would not change our results. In this specific setting, the optimal cash holding always equals zero, because the low returns earned on cash reduces banks' overall profitability and generates thinner buffers against fire-sale losses. Despite of the fact that cash helps to avoid loan fire-sales in the first place, funding liquidity is not reduced by greater cash holding.

${ }^{8}$ Assuming a flat deposit insurance premium that is based on the expected equilibrium debt ratio will not qualitatively change our results.
} 
A bank's loan portfolio takes two periods to mature. When facing early withdrawals, a bank has to sell part (or all) of its assets in a secondary market at a fire-sale discount. The liquidity mismatch leads to the risk of bank runs. To model the fire sale, we assume that by selling one unit of asset that generates cash flow $\theta$, the bank obtains only a fraction of it.

$$
\frac{\theta}{1+\lambda}
$$

Here $\lambda>0$ reflects the illiquidity of banks' long-term assets that can be attributed to moral hazard, e.g., bankers' inalienable human capital in monitoring entrepreneurs, or adverse selection, e.g., buyers concerned with banks selling their 'lemon' loans. ${ }^{9}$ We focus on the natural case where runs make it more difficult for a bank to repay its debts, which occurs when the discount on the value of assets is greater than that on liabilities. ${ }^{10}$

$$
\frac{1}{1+\lambda}<q
$$

Inequality (3) captures the liquidity mismatch between banks' asset and liabilities, stating that it is costly to pay for short-term deposit withdrawals with the sale of long-term assets. If the condition is not satisfied, we will have a paradoxical scenario where banks can more easily meet their debt obligations in fire sales, and an insolvent bank with $\theta<D+F$ will be saved by a bank run, provided $(1+\lambda) q D+F<\theta$.

\subsection{Endogenous leverage}

Banks set their leverage in order to maximize the equity value of existing shareholders. Since retail deposit is fixed in supply $\left(V_{F}=F\right)$, each bank optimizes on the amount of wholesale debt claims $D$.

We assume that the cost of capital is higher than the cost of debt and denote by $k$ the equity premium. So the expected return on capital is $1+k$. The classical justification of the equity premium would be the tax benefits of debt. Alternative justifications include the dilution costs à la Myers and Majluf (1984) and the renegotiation costs à la Diamond and Rajan (2000). ${ }^{11}$

\footnotetext{
${ }^{9}$ The alternative assumption of banks using collateralized borrowing generates similar results. See Morris and Shin (2009). In that case, $1 /(1+\lambda)$ reflects the hair-cut in the collateralized borrowing.

${ }^{10}$ Note also that condition (3) is always true as $q$ approaches 1.

${ }^{11}$ When a corporate tax is levied at a constant rate $\tau$ and debt repayments are exempted, $k$ reflects the cost of losing tax shields. With $1+k=1 /(1-\tau)$ or $\tau=k /(1+k)$, the model will provide the familiar expression that firms trade off between tax shields and bankruptcy costs.
} 
In the presence of bankruptcy costs, the optimal leverage will trade off between the cost of equity and the expected cost of bankruptcy. The existence of liquidity risk makes the choice of leverage slightly more complex, because when evaluating the chance of bankruptcy, banks need to take into account both insolvency and illiquidity risk.

\subsection{Time line}

The timing of the model is summarized in the figure below.

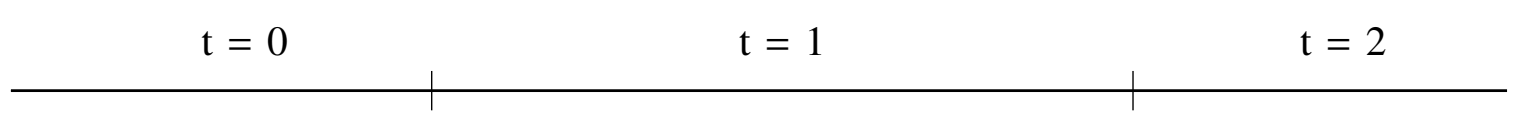

1. Banks choose capital 1. Wholesale creditors decide to run structure $(D)$. or not after observing private signals.

2. Entrepreneurs choose

$P$ for a given $r$.
2. Banks that face runs sell their assets at a discount.

3. Banks fail or survive.
1. Returns realize for surviving banks.

2. Wholesale creditors who have not run get paid provided that their bank does not fail.

\section{Banking risks with exogenous leverage}

In this section, we show that competition can affect different types of bank risk differently. We move upward the spectrum of types of risk: from loan and portfolio risk, to insolvency risk, and to the risk of being solvent but illiquid. We extend the model in section 5.1 to incorporate also systemic risk and contagion.

\subsection{Loan portfolio risk}

In the spirit of Boyd and De Nicolo (2005), we show that bank competition reduces loan default risk by curbing entrepreneurs' moral hazard. Note that entrepreneurs' utility maximization yields the following probability of success. ${ }^{12}$

$$
P_{b}^{*}= \begin{cases}1 & \text { if } b \in[1 /(x-r), B] \\ b(x-r) & \text { if } b \in(0,1 /(x-r))\end{cases}
$$

\footnotetext{
${ }^{12}$ Entrepreneurs' participation constraints are always satisfied, because their expected utility is non-negative for optimal $P_{b}^{*}$.
} 
While an entrepreneur of type $b \geq 1 /(x-r)$ will not default for any finite realization of $z$, loans issued to entrepreneurs of lower types can default. This makes a natural partition between risk-free and risky loans. Given the uniform distribution of $b$, a fraction $\alpha$ of loans

$$
\alpha \equiv 1-\frac{1}{B(x-r)}
$$

are risk free, and the complementary fraction $(1-\alpha)$ of loans are risky and have positive probabilities of default. The riskiness of a bank's loan portfolio is therefore reflected by $1-\alpha$, with a smaller $\alpha$ associated with higher risk.

As in Boyd and De Nicolo (2005), the riskiness of loan portfolio decreases with banking competition. When banks charge lower loan rates under fierce competition, entrepreneurs have more 'skin in the game' and therefore take less risk. As a result, the pool of safe loans grows.

$$
\partial \alpha / \partial r=\frac{-1}{B(x-r)^{2}}<0
$$

We further characterize banks' loan and portfolio risk by deriving the distribution of loan losses and that of cash flows. Denote the fraction of non-performing loans in the risky pool by $\gamma$. We show that $\gamma$ follows a uniform distribution on $[0,1]$. This suggests that the expected loan loss in the risky pool is always $1 / 2$. The riskiness of a loan portfolio solely depends on the size of the risky pool. When the risky pool shrinks under competition, the bank's portfolio risk decreases.

Lemma 1. The loan loss $\gamma$, defined as the fraction of loan defaults in the risky pool, follows a uniform distribution on $[0,1]$.

Proof. See Appendix A.1.

A loan portfolio generates the following cash flow $\theta$.

$$
\theta \equiv \alpha r+(1-\alpha)[0 \cdot \gamma+r \cdot(1-\gamma)]=r-(1-\alpha) r \gamma
$$

The stochastics of the cash flow is driven by the random loan loss $\gamma$. Since $\gamma$ enters the expression linearly, the cash flow $\theta$ also follows a uniform distribution, on support $[\alpha r, r]$. Figure 1 depicts two cumulative distribution functions of cash flows, associated with different levels of competition. When competition intensifies (loan rate drops from $r^{\prime}$ to $r$ ), the distribution 
Figure 1: Cash flow distribution under two different levels of competition

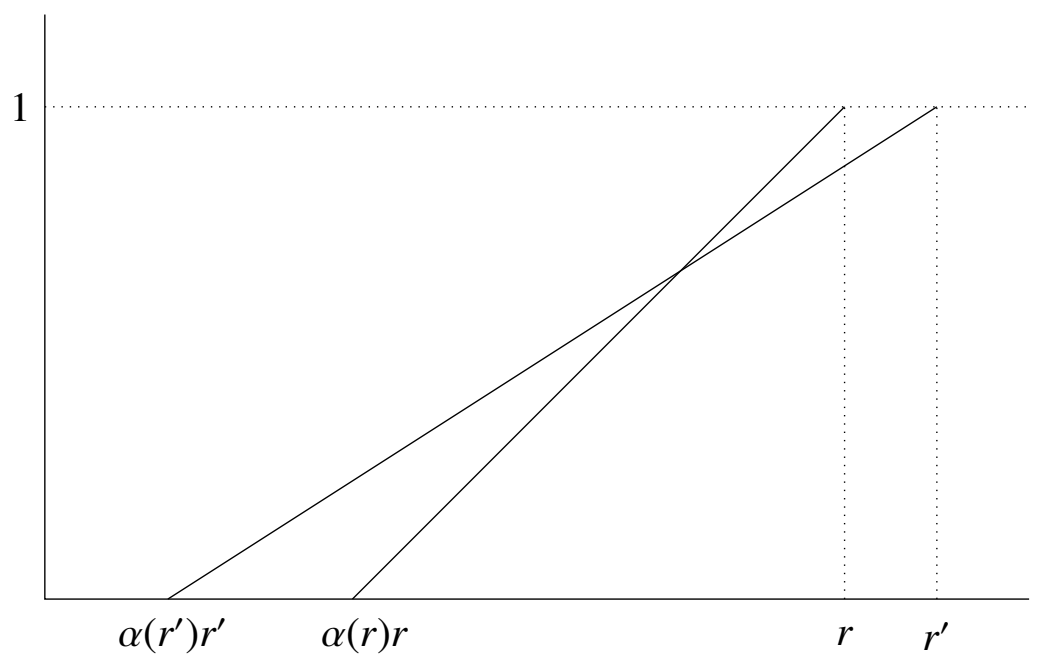

function becomes steeper, implying cash flow less volatile. Analytically, one can show that $\sigma(\theta)=(1-\alpha)^{2} r^{2} \sigma(\gamma)$, monotonically increasing in $r$.

Lemma 2. A bank's loan portfolio generates a random cash flow $\theta \sim U(\alpha r, r)$. When competition reduces loan rate $r$, the volatility of cash flow decreases.

\subsection{Insolvency risk}

Less risk-shifting and lower portfolio risk, however, do not necessarily imply a lower bank insolvency risk, because competition also reduces bank profits which can be used as a buffer against loan losses. In this subsection, we study how competition affects a bank's insolvency risk for a given level of debt.

A bank is solvent if its cash flow meets its liability, $\theta=r-(1-\alpha) r \gamma \geq F+D$. The inequality gives a critical level of loan loss, $\hat{\gamma}$.

$$
\hat{\gamma} \equiv \frac{r-(F+D)}{(1-\alpha) r}
$$

A bank with a realized loan loss greater than $\hat{\gamma}$ will become insolvent. For $\gamma \sim U(0,1)$, this implies that the solvency probability is equal to $\hat{\gamma}$. A bank's pure insolvency risk $\rho_{S R}$, i.e., the risk of failure in the absence of bank runs, takes the following form.

$$
\rho_{S R} \equiv 1-\hat{\gamma}=\frac{(F+D)-\alpha r}{(1-\alpha) r}
$$


Note that insolvency risk is not monotonic in $r$. The reason is the same as in Martinez-Miera and Repullo (2010). Banking competition has two countervailing effects on insolvency: On one hand, lower loan rates reduce entrepreneurs risk-taking so that loan losses decrease (riskshifting reduction effect). On the other hand, competition also makes banks' interest margin thinner and banks less profitable, reducing the buffer available to absorb loan losses (buffer reduction effect). The overall effect depends on parameters and is characterized in the following proposition.

Proposition 1. For a given capital structure, a bank's insolvency risk is reduced by competition if and only if $r^{2}>x(F+D)$.

Proof. See Appendix A.2.

The intuition behind condition $r^{2}>x(F+D)$ is as follows. When project returns $x$ are sufficiently high, entrepreneurs will have enough stake in their projects, and the change of loan rate will not substantially affect their incentive to take risk (analytically, note that $\partial^{2}(1-$ $\alpha) / \partial x \partial r<0)$. In this case, the reduced loan rate under competition mainly translates into a thinner capital buffer against loan losses. Therefore, for $x>r^{2} /(F+D)$, the buffer reduction effect dominates and competition increases insolvency. Graphically, $r^{2}>x(F+D)$ is equivalent to two conditions: (1) $\partial(\alpha r) / \partial r>0$ so that the distribution function satisfies a single crossing condition, and (2) the face value of debt should be to the left of the crossing point. Figure 2 illustrates such a scenario: As banking competition weakens and the loan rate rises from $r$ to $r^{\prime}$, solvency probability drops from $\rho_{S R}$ to $\rho_{S R}^{\prime}$.

Figure 2: Change of insolvency risk under exogenous leverage

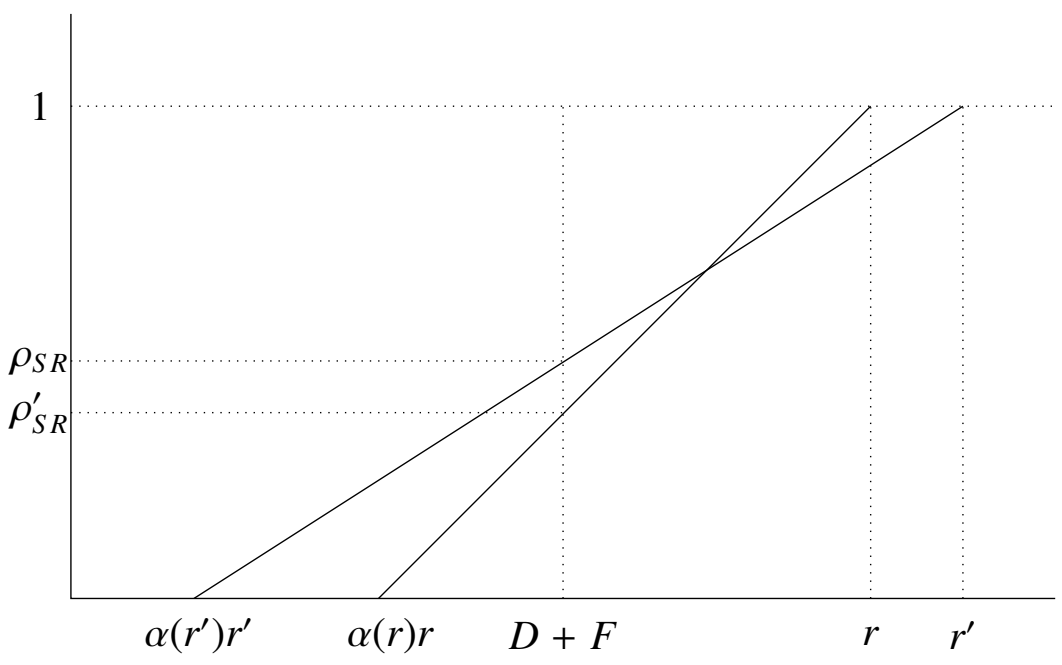




\subsection{Funding liquidity risk and bank run}

In this section we use the global games approach of Carlsson and Van Damme (1993) to examine banks' funding liquidity risk. We derive a critical level of cash flow below which a bank becomes solvent but illiquid: being able to repay its $t=2$ liability in full if no one runs on it at $t=1$, but going to default if sufficient many wholesale creditors withdraw early. Such a panic, or speculative bank run, can be found in papers like Morris and Shin (2000), Goldstein and Pauzner (2005), and Rochet and Vives (2004). Yet in our paper global games are not as much front and center, but rather used as a modeling device that allows us to define funding liquidity risk and to study how competition affects it.

In principle, a bank can fail because of illiquidity either at $t=1$ or $t=2$. In the former case, the liquidation value of all assets is insufficient to repay early withdrawals. In the latter case, while partial liquidation generates sufficient cash to repay early withdrawals, the residual portfolio is insufficient to repay creditors who wait until $t=2$. Here we focus on the second case, and assume that banks can always cover their liquidity needs at $t=1$ even if all wholesale creditors run on the bank. ${ }^{13}$ Analytically, this requires inequality $\theta /(1+\lambda)>q D$ to be satisfied for even the lowest possible $\theta$. That is, $\alpha r>(1+\lambda) q D .{ }^{14}$ Denote by $L$ the fraction of wholesale financiers who run on the bank. A bank survives $t=1$ withdraws but fails at $t=2$ if the fraction of early withdrawals exceeds the following threshold.

$$
L>\frac{\theta-F-D}{[(1+\lambda) q-1] D}
$$

A creditor's decision to run or not depends on both her signal $s_{i}=\theta+\epsilon_{i}$ and her belief concerning other agents' actions. Creditors play a switching strategy: They run on the bank if the observed signal is smaller than a critical level. The equilibrium is characterized by a unique critical level $s^{*}$.

Our assumption of the lack of common knowledge leads to so-called Laplacian property of global games: No matter what signal that a player $i$ observes, he has no information on the rank of his signal as compared to the signals observed by the other players. Denote by $M$ the

\footnotetext{
${ }^{13} \mathrm{We}$ focus on this case because the alternative assumption that banks fail at $t=1$ entails rather extreme parameters, and does not hold once leverage is endogenous.

${ }^{14}$ One can also verify that this condition is satisfied at the optimal debt level in section 4.1 .
} 
fraction of players that the player $i$ believes to observe a higher signal than his. The Laplacian property implies $M \sim[0,1]{ }^{15}$

Since the Laplacian property holds for all players and in particular for the creditor who observes the critical signal $s^{*}$, the creditor will hold a belief that $M \sim U(0,1)$ fraction of players will not run on the bank and the rest $(1-M)$ will. Combined with condition (7), he anticipates the bank to survive with a probability $(\theta-F-D) /[(1+\lambda) q-1] D$.

The critical cash flow level $\theta^{*}$ is characterized by the indifference between running on the bank or not for the creditor who observes signal $s^{*}$.

$$
\operatorname{Prob}\left(t=1 \operatorname{survival} \mid s=s^{*}\right) \cdot q D=\operatorname{Prob}\left(t=2 \operatorname{survival} \mid s=s^{*}\right) D
$$

Given $\operatorname{Prob}\left(t=1 \operatorname{survival} \mid s=s^{*}\right)=1$ and $\operatorname{Prob}\left(t=2 \operatorname{survival} \mid s=s^{*}\right)=(\theta-F-D) /[(1+\lambda) q-$ 1] $D$, the indifference condition can be rewritten as $q=\frac{\theta-F-D}{[(1+\lambda) q-1] D}$, which implies the following critical cash flow $\theta^{*}$.

$$
\theta^{*}=F+D+q[(1+\lambda) q-1] D
$$

A run successfully happens when a bank's cash flow $\theta$ falls below the critical level $\theta^{*}$. Define $\mu \equiv 1+q[(1+\lambda) q-1]$. A bank is solvent but illiquid if

$$
F+D<\theta \leq F+\mu D
$$

where $\mu>1$ because $(1+\lambda) q>1$. Intuitively, in order to survive potential bank runs, a bank has to make more profit than what is required to be barely solvent. Also the critical cash flow increases in $\lambda$ and $D$, because greater fire-sale losses and more exposure to unstable short-term funding lead to a higher chance of illiquidity.

Proposition 2. There exists a critical level $\theta^{*}=F+\mu D, \mu=1-q[1-(1+\lambda) q]>1$, such that a bank that has cash flow $\theta \in\left[F+D, \theta^{*}\right]$ is solvent but illiquid.

Proposition 2 states that banks with $\theta \in\left[F+D, \theta^{*}\right]$ face pure liquidity risk. These banks are solvent in the absence of bank runs, but will fail if a run occurs. For $\theta \sim U[\alpha r, r]$, the

\footnotetext{
${ }^{15}$ More detailed discussion of the property can be found in Morris and Shin (2001) and we reproduce the proof in Appendix B.
} 
probability of a bank being solvent but illiquid can be calculated as follows. ${ }^{16}$

$$
\rho_{I L} \equiv \frac{(\mu-1) D}{(1-\alpha) r}
$$

When a bank's wholesale debt $D$ is exogenous, the pure liquidity risk will increase with competition. The result follows directly from the comparative statics.

$$
\frac{\partial \rho_{I L}}{\partial r}=(\mu-1) \frac{-D}{(1-\alpha)^{2}} \frac{\partial(1-\alpha)}{\partial r}<0
$$

Intuitively, competition contributes to illiquidity by reducing the expected cash flows. For a given level of fire-sale losses $(\lambda)$ and a given level of wholesale debt $(D)$, the lower cash flow due to intensified competition leads to a thinner buffer against fire-sale losses. Creditors who withdraw early will then cause a greater loss to those who wait. As the negative externalities aggravate, the coordination failure will happen more frequently among the wholesale creditors, and therefore a bank run becomes more likely.

In practice, it is difficult to distinguish between bank failures due to insolvency and those due to illiquidity. Given the observational equivalence, it is useful to examine a bank's total credit risk $\left(\rho_{T C R}\right)$, i.e., the probability of bankruptcy for either solvency or liquidity reasons. Since pure insolvency and pure illiquidity are disjoiont event, we have the total credit risk $\rho_{T C R} \equiv \operatorname{Pr}\left(\theta<\theta^{*}\right)=\operatorname{Pr}(\theta \leq D+F)+\operatorname{Pr}\left(D+F<\theta \leq \theta^{*}\right)=\rho_{S R}+\rho_{I L}$.

$$
\rho_{T C R}=\frac{(F+\mu D)-\alpha r}{(1-\alpha) r}
$$

Examining the first order derivative with respect to $r$, one can verify that banking competition reduces total credit risk $\left(\partial \rho_{T C R} / \partial r>0\right)$ if and only if

$$
r^{2}>x(F+\mu D)
$$

Note that condition (10) is more stringent than the condition in Proposition 1. Once funding liquidity risk is taken into account, for a parameter constellation satisfying $x(F+\mu D)>r^{2}>$ $x(F+D)$, banking competition would decrease pure insolvency risk but increase total credit

\footnotetext{
${ }^{16}$ Contrary to the pure insolvency risk, the amount of stable funds provided by insured deposits, $F$, is absent from the above measure of risk, as retail depositors do not have any incentive to run on the bank. The same would hold true for long-term debts, as by definition their contract make it impossible for the claim holders to run the bank.
} 
risk. In other words, when illiquidity risk is considered, the set of parameters where the result of Boyd and De Nicolo (2005) applies will shrink.

Proposition 3. For a given level of debt obligation, the probability for a bank to be solvent but illiquid monotonically increases with competition. The total credit risk, defined as the risk of bank failures due to either insolvency or illiquidity, decreases with competition if and only if $r^{2}>x(F+\mu D)$.

Proposition 1 and 3 suggest that even if banks do not adjust their leverage according to changing competitive environment, competition can affect different types of bank risk differently. Focusing on solely one dimension of risk can lead to biased judgment for the overall effects.

\section{Endogenous leverage and its impacts}

Although banks' leverage decision are restricted by regulation, banks still have the ability to choose the buffer above and beyond regulatory capital requirements as well as the maturity structure of their debt. Leverage plays a crucial role in the determination of insolvency risk: A low-risk portfolio financed with high leverage can end up generating a high insolvency risk. Consequently, the bank's optimal leverage choice may offset any reduction in the portfolio risk due to competition. It is therefore crucial to study how the previous results change upon the introduction of endogenous leverage.

\subsection{Endogenous leverage}

While a higher debt level saves on costly capital, it also entails a greater chance of bankruptcy (caused by either insolvency or illiquidity). Banks rationally set their leverage to equalize the marginal cost and the marginal benefit.

\subsubsection{The general case}

Banks choose their capital structure to maximize the leveraged firm value to existing shareholders. If $\omega$ is the fraction of the bank sold to new shareholders, existing shareholders obtain

$$
(1-\omega) \int_{F+\mu D}^{\bar{\theta}}[\theta-F-D] h(\theta, r) d \theta,
$$


where bank cash flow $\theta$ has a density function $h(\theta, r)$ on support $[\underline{\theta}, \bar{\theta}]$. The bank will raise $V_{E}$ from new shareholders, $V_{D}$ from wholesale short term creditors, and $V_{F}=F$ from insured depositors. And the three sources of funding should provide the required amount of investment, $V_{E}+V_{D}+V_{F}=1$. The optimal leverage is the solution to the maximization program below.

$$
\begin{aligned}
\max _{\omega, D}\left\{(1-\omega) \int_{F+\mu D}^{\bar{\theta}}[\theta-F-D] h(\theta, r) d \theta\right\} \\
\text { s.t. } \quad V_{E}=\frac{\omega}{1+k} \int_{F+\mu D}^{\bar{\theta}}[\theta-D-F] h(\theta, r) d \theta \\
V_{D}=\int_{F+\mu D}^{\bar{\theta}} D h(\theta, r) d \theta \\
V_{F}=F \\
V_{E}+V_{D}+V_{F}=1
\end{aligned}
$$

Adding the three constraints to the objective function we obtain the unconstrained optimization, with $\int_{\underline{\theta}}^{F+\mu D} F h(\theta, r) d \theta$ reflecting the subsidy of deposit insurance.

$$
\max _{D}\left\{\int_{F+\mu D}^{\bar{\theta}}[\theta+k(F+D)] h(\theta, r) d \theta+(1+k) \int_{\underline{\theta}}^{F+\mu D} F h(\theta, r) d \theta-(1+k)\right\}
$$

The optimization program yields the following first order condition.

$$
-\mu\left[\left(F+\mu D^{*}\right)+k\left(F+D^{*}\right)\right] h\left(F+\mu D^{*}, r\right)+\int_{F+\mu D^{*}}^{\bar{\theta}} k h(\theta, r) d \theta+(1+k) \mu F h\left(F+\mu D^{*}, r\right)=0,
$$

which can be written compactly as

$$
-\mu(\mu+k) D^{*} h\left(F+\mu D^{*}, r\right)+\int_{F+\mu D^{*}}^{\bar{\theta}} k h(\theta, r) d \theta=0
$$

or with $H$ denoting the c.d.f. of $\theta$,

$$
D^{*}=\frac{k\left[1-H\left(F+\mu D^{*}, r\right)\right]}{\mu(\mu+k) h\left(F+\mu D^{*}, r\right)}
$$

Note that equation (12) is an implicit (potentially non-linear) function of $D^{*}$. The analytical solution is generally difficult to obtain. 


\subsubsection{Application to our setup}

The uniform distributions in the current paper will greatly simplify the model. It is especially convenient to work with the loan loss $\gamma \sim U(0,1)$. To facilitate exposition, we denote

$$
\hat{\gamma}_{\mu} \equiv \frac{r-(F+\mu D)}{(1-\alpha) r}
$$

$\hat{\gamma}_{\mu}$ is a counterpart of $\hat{\gamma}$ : It defines a critical loan loss the bank will survive once liquidity risk is taken into account. The general optimization program then takes the following specific form.

$$
\begin{aligned}
& \max _{\omega, D}\left\{(1-\omega) \int_{0}^{\hat{\gamma}_{\mu}}[\theta-F-D] d \gamma\right\} \\
& \text { s.t. } \quad V_{E}=\frac{\omega}{1+k} \int_{0}^{\hat{\gamma}_{\mu}}[\theta-D-F] d \gamma \\
& V_{D}=\int_{0}^{\hat{\gamma}_{\mu}} D d \gamma \\
& V_{F}=F \\
& V_{E}+V_{D}+V_{F}=1
\end{aligned}
$$

After substituting the constraints, the program simplifies to:

$$
\max _{D}\left\{\int_{0}^{\hat{\gamma}_{\mu}}[\theta+k(D+F)] d \gamma+(1+k) \int_{\hat{\gamma}_{\mu}}^{1} F d \gamma-(1+k)\right\}
$$

The maximization program has the following first order condition ${ }^{17}$

$$
\left[r \frac{\partial \hat{\gamma}_{\mu}}{\partial D}-\frac{(1-\alpha) r}{2} 2 \hat{\gamma}_{\mu} \frac{\partial \hat{\gamma}_{\mu}}{\partial D}\right]+k \hat{\gamma}_{\mu}+k\left(F+D^{*}\right) \frac{\partial \hat{\gamma}_{\mu}}{\partial D}-(1+k) F \frac{\partial \hat{\gamma}_{\mu}}{\partial D}=0
$$

and yields the optimal level of risky debt

$$
D^{*}=\frac{r-F}{\mu^{2} / k+2 \mu}
$$

The result is summarized in the following theorem.

Proposition 4. A bank that maximizes its value by trading off the benefits of debt versus its bankruptcy cost sets its debt to $D^{*}=(r-F) /\left[\mu^{2} / k+2 \mu\right]$.

\footnotetext{
${ }^{17}$ It is straightforward to check that the second order condition is satisfied, $-(1-\alpha) r\left(\frac{\partial \hat{\gamma}_{\mu}}{\partial D}\right)^{2}+2 k \frac{\partial \hat{\gamma}_{\mu}}{\partial D}<0$.
} 
The risky debt that a bank issues is proportional to its maximum residual cash flow after paying insured deposits $F$. In particular, $D^{*}$ increases in the cost of capital $k$, and decreases in the accosiated liquidity risk $\mu .^{18}$

\subsection{Risk under endogenous leverage}

With exogenous leverage $D$ replaced by endogenous $D^{*}$, the different bank risks under endogenous leverage are defined analogously as in equations (6) and (8) - (9). Denote the risks accordingly with a superscript star. One can write insolvency risk, liquidity risk, and total credit risk as follows.

$$
\begin{aligned}
\rho_{S R}^{*} & \equiv 1-\frac{r-F-D^{*}}{(1-\alpha) r}=1-\left[1-\frac{1}{\mu^{2} / k+2 \mu}\right] \frac{r-F}{(1-\alpha) r} \\
\rho_{I L}^{*} & \equiv(\mu-1) \frac{D^{*}}{(1-\alpha) r}=\frac{\mu-1}{\mu^{2} / k+2 \mu} \frac{r-F}{(1-\alpha) r} \\
\rho_{T C R}^{*} & \equiv 1-\frac{r-F-\mu D^{*}}{(1-\alpha) r}=1-\frac{\mu+k}{\mu+2 k} \frac{r-F}{(1-\alpha) r}
\end{aligned}
$$

How competition affects bank risks under endogenous leverage follows directly from the comparative statics.

Proposition 5. If $r^{2}>x F$, pure insolvency and total credit risk decreases as competition intensifies, whereas funding liquidity risk increases. Otherwise, the result reverses. Therefore, under endogenous leverage, pure insolvency and liquidity risk always move in the opposite direction, with the latter dominant in determining total credit risk.

Proof. See Appendix A.4.

\subsection{Exogenous vs. exogenous leverage}

The endogenous leverage has a crucial impact on the various risks already identified. In some instances, it reverses the results obtained under exogenous leverage. To emphasize this, we summarize in Table 1 and 2 the results under exogenous and endogenous bank leverage for a side-by-side comparison.

Table 1: Banking competition and risk under exogenous leverage

\footnotetext{
${ }^{18}$ Note that $\lim _{\mu \searrow 1} 1 /\left[\mu^{2} / k+2 \mu\right]=1 /(1 / k+2)<1$. Since $1 /\left[\mu^{2} / k+2 \mu\right]$ monotonically decreases in $\mu$, it holds that $1 /\left[\mu^{2} / k+2 \mu\right]<1 /(1 / k+2)<1$. A bank cannot issue more risky debt claims than its maximum cash flow after paying the risk-free $F$ and is unwilling to issue risky debt more than a fraction of $(r-F)$.
} 


\begin{tabular}{lcccc} 
& $r^{2}<x(F+D)$ & $r^{2} \in\left[x(F+D), x \theta^{*}\right)$ & $r^{2} \in\left[x \theta^{*}, x \theta^{* *}\right)$ & $r^{2}>x \theta^{* *}$ \\
\hline \hline Pure insolvency risk & + & - & - & - \\
\hline Pure liquidity risk & + & + & + & + \\
\hline Total credit risk & + & + & - & - \\
\hline \hline
\end{tabular}

A '+' sign ('-' sign) denotes that competition increases (decreases) the bank risk considered.

Table 2: Banking competition and risk under endogenous leverage

\begin{tabular}{lll} 
& $r^{2}<x F$ & $r^{2}>x F$ \\
\hline \hline Pure insolvency risk & + & - \\
\hline Pure liquidity risk & - & + \\
\hline Total credit risk & + & - \\
\hline \hline
\end{tabular}

A '+' sign ('-' sign) denotes that competition increases (decreases) the bank risk considered.

\subsection{Interpretation}

Overall, our results state that the impact of competition on financial stability critically depend on the type of banking industry that is considered. Two possible cases emerge. The case $r^{2}>x F$, corresponds to less productive firms facing high borrowing costs, while banks obtain high margins and raise funding in the market (low level of insured deposits). When this is the case, total credit risk is reduced with competition. As a limit case, $F=0$ can be interpreted as investment banking. More competition means safer investment banking. Alternatively, the case $r^{2}<x F$, corresponds to highly productive firms facing low borrowing costs, with banks mainly financed through deposits. In such environment, the opposite result holds: banking competition reduces financial stability. This correspond to classical retail banking with low margents and prudent funding through insured deposits.

Although our model does not pretend to provide robust results that hold true in every environment, it is worth noticing the key ingredients that determine here the impact of bank competition on the different types of financial stability. As shown by inequality (A.23), banks' liability structure, and in particular the amount of short term wholesale funding, is central to the relationship between competition and bank risk. Our model's conclusions provide a much richer view of the link between banking competition and financial risk than is usually considered.

1. To begin with, notice that the result depends upon the borrowing firms' project returns $x$. For a given level of deposits and banks' market power, the effect of banking competition on 
financial stability depends upon how productive the firms are. In highly productive economies, bank competition constitutes a threat to financial stability. The impact of moral hazard is reduced, and the key determinant of the link between bank competition and financial stability is the role of the buffer generated by banks' market power. Comparing Proposition 1 and Proposition 6 we observe that the threshold for $x$ that inverts the relationship from banking competition to financial stability is reached much earlier if we take into account the endogeneity of banks' leverage. This is the case because banks will be more conservative in their choice of leverage, so that the strength of the Boyd and De Nicolo's argument is weakened and the charter value dominates. The argument can be reinterpreted considering the business cycle. In a boom, banking competition jeopardizes financial stability, while, in a bust it reduces banks' risks.

2. The level of market power is also essential in our framework. For high market power competition reduces bank fragility, nevertheless a threshold may exist (provided that $x F>1$ ) beyond which the result is reserved. This is interesting from a policy perspective as it provides a more nuanced prescription than the usual one: in order to sustain financial stability, it might be interesting to promote competition up to a certain threshold, but beyond that point, competition will lead to higher banking risk.

3. The role of stable funds is critical for our result. In a traditional banking industry funded through deposits and long term bonds (equivalent in our context to insured deposits) where $x F>r^{2}$, competition will be detrimental to financial stability. Instead in a banking industry where wholesale short term (possibly interbank) funding is prevalent, the Boyd De Nicolo argument will prevail.

4. More generally, two types of banks, corresponding to the two possible signs of $x F-$ $r^{2}$, may coexist and will react in a different way to an increase in competition. For banks that rely less on stable funding $x F<r^{2}$, in particular for investment banks, an increase in competition will increase financial stability. Instead, for banks with high levels of deposits and lower market power, for which the inequality $x F>r^{2}$ is fulfilled, the opposite occurs and banking competition's main effect is to reduce the banks buffer and to encourage higher leverage. 


\section{Extension: contagion and systemic risk}

A natural extension is to explore what happens once we add the risk of financial contagion. We illustrate this in a two-bank setup, with two bank failures at the same time considered as a systemic crisis. ${ }^{19}$ We make a stylized assumption that when both banks need to sell, the fire-sale discount hikes from $\lambda$ to $\lambda^{\prime}$. This assumption captures the observation that secondary market prices tend to fall further when more banks fail and are forced to sell their assets. ${ }^{20}$ Therefore, asset fire sales provide a channel of financial contagion: When the first bank goes under, asset prices decline, which magnifies the coordination failure among the debt holders at the other bank, leading to a second bank run. ${ }^{21}$

Following the structure of section 3 and 4, we first study how competition affects contagion and systemic risk under the assumption of exogenous leverage, and then move on to the case of endogenous leverage.

\subsection{Contagion and systemic risk under exogenous leverage}

Following the same procedure of section 3.4, one can derive a critical cash flow level

$$
\theta^{* *}=F+\mu^{\prime} D>\theta^{*}
$$

with $\mu^{\prime}=1-q\left[1-\left(1+\lambda^{\prime}\right) q\right]>\mu$. A bank whose cash flow falls between $\left[\theta^{*}, \theta^{* *}\right]$ will not fail if the other bank does not face a run, but will fail because of illiquidity if a run happen to the other bank. Therefore, a bank of $\theta \in\left[\theta^{*}, \theta^{* *}\right]$ is exposed to contagion. We define the risk of contagion as follows.

$$
\rho_{C T G} \equiv \operatorname{Prob}\left(\theta^{*}<\theta<\theta^{* *}\right)=\frac{\left(\mu^{\prime}-\mu\right) D}{(1-\alpha) r}
$$

A systemic crisis happens when the two banks fail simultaneously, which incurs with the following probability.

$$
\rho_{S Y S}=\operatorname{Prob}\left(\theta<\theta^{* *}\right)^{2}=\left[\frac{\theta^{* *}-\alpha r}{(1-\alpha) r}\right]^{2}
$$

\footnotetext{
${ }^{19}$ The extension to $n$ banks is straightforward.

${ }^{20}$ The decline of asset prices can be caused either by cash-in-the-market pricing or by informational contagion. In the former case, market prices are driven down by the limited supply of cash. In the latter, a large number of bank failures leads investors to form more pessimistic beliefs of banks' common risk exposures and lowers their willingness to pay for bank assets.

${ }^{21}$ For a full-fledged model where fire sales and bank runs mutually reinforce, see Li and Ma (2012).
} 
Figure 3: Illustration of Various Bank Risk

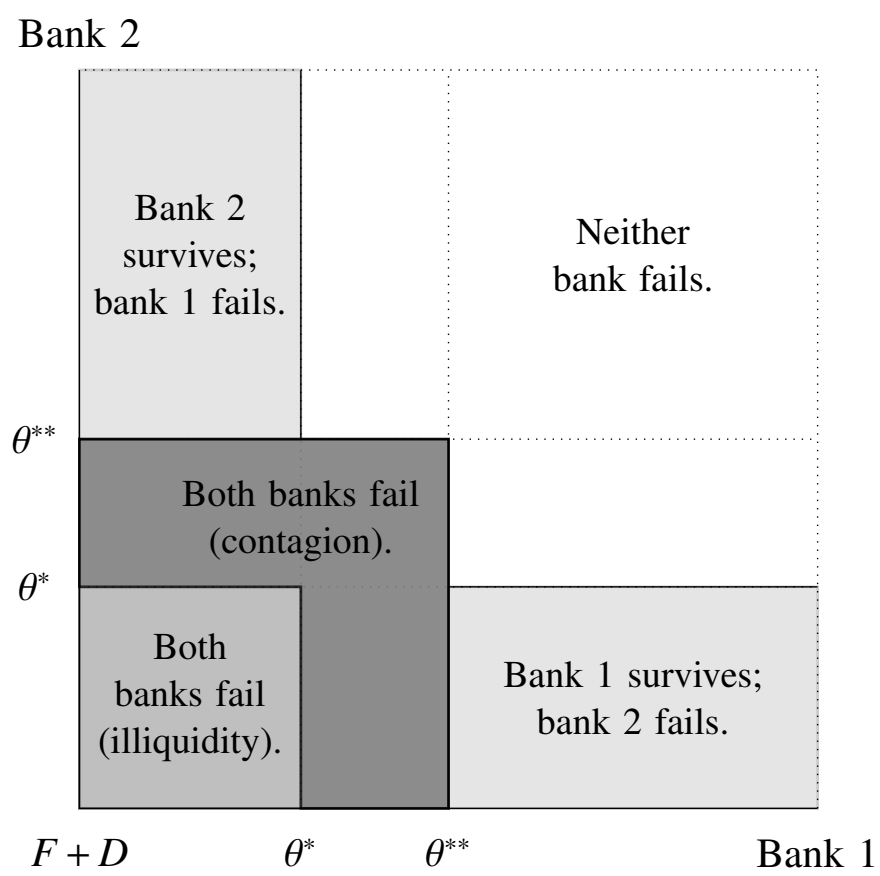

The liquidity risk, the exposure to contagion, and the risk of a systemic crisis are illustrated in Figure 3. As the competitive environment changes, the critical cash flow $\theta^{*}$ and $\theta^{* *}$ shift, leading to the corresponding changes in various bank risks.

Competition affects systemic risk in two ways. First, it reduces banks' buffer against firesale losses, and therefore incerases banks' exposure to contagion. On the other hand, it promotes banks' solvency if $r^{2}>x(F+D)$, reducing the chance of the 1st first firesale. Overall, competition reduces systemic risk if and only if $r^{2}>x\left(F+\mu^{\prime} D\right)$, which forms a counterpart to condition (10).

Proposition 6. For a given level of debt obligation, banks' exposure to contagion increases with competition. Competition reduces the risk of systemic crises if and only if $r^{2}>x\left(F+\mu^{\prime} D\right)$.

Proof. See Appendix A.3.

\subsection{Contagion and systemic risk under endogenous leverage}

To simplify the analysis under endogenous leverage, we assume that regulators bail out both banks in a systemic crisis so that banks do not to take into account systemic risk when setting 
their leverage. ${ }^{22}$ Consequently, the optimal wholesale debt remains the same as in equation (14). Substituting that into (18) and (19), we obtain the probability of contagion and systemic crisis under endogenous leverage.

$$
\begin{aligned}
& \rho_{C T G}^{*} \equiv \frac{\left(\mu^{\prime}-\mu\right) D^{*}}{(1-\alpha) r} \\
& \rho_{S Y S}^{*} \equiv \operatorname{Prob}\left(\theta<\theta^{* *}\right)^{2}=\left(1-\frac{r-F-\mu^{\prime} D^{*}}{(1-\alpha) r}\right)^{2}
\end{aligned}
$$

The impact of competition on banks' exposure to contagion $\left(\rho_{C T G}^{*}\right)$ and the risk of a systemic crisis $\left(\rho_{S Y S}^{*}\right)$ simply follow the comparative statics.

Proposition 7. For $r^{2}>x F$, while banks' exposure to financial contagion increases with competition, the risk of a systemic crisis decreases, provided $\mu^{\prime} c<1$.

Proof. See Appendix A.5.

To a large extent, the model presented a special case in the sense that its analytical solution is not easily generalizable. Yet the result still conveys the key messages of the paper: (1) banking competition affects different types of risk differently; and (2) endogenous leverage is a central hub that both reflects changes in the cash flow riskiness and affects all different aspects of banking risk.

We consider our model as a special case also because we take risk-shifting hypothesis as a priori to start with. The argument of endogenous leverage is however more general and also applies to models that take charter value hypothesis as a priori. In that case, when competition induces banks to choose riskier portfolios with lower charter values, banks will optimally adjust their leverage to balance the change in the portfolio risk. Again, leverage and risks will be jointly determined by banks' optimization behaviors. Yet as the priori flips, the overall results might reverse as compared to those in the current paper.

\footnotetext{
${ }^{22}$ Relaxing this assumption would imply negative externalities of leverage: A bank that fails because of high leverage is contagious to other banks. Since such cost is not taken into account in private decisions, banks are likely to use greater leverage.
} 


\section{Reinterpreting the empirical literature}

The difficulties in analyzing the link between competition and stability exponentially increase when we turn to empirical studies, which have led to a multiplicity of results that are sometimes hard to reconcile. ${ }^{23}$

Our model aims to clarify and reconcile the literature by suggesting that bank risks should be measured at four fundamentally different levels (asset risk, insolvency, illiquidity, and the systemic risk) and competition can affect different risks differently. ${ }^{24}$ In our model, competition affects banks' asset risk directly by reducing borrowers' risk-shifting. But as banks react to the changes of asset risk by altering their leverage, all other types of risks are indirectly affected. Therefore our reading of the empirical literature introduces drastic differences depending on whether the evidence concerns the riskiness of banks' assets, or the riskiness of banks themselves. We suggest a progressive approach to understand the impact of competition on banks' risk-taking by refining the questions that are asked as successive layers.

1. Does competition increase the safety banks' portfolios? In other words, is Boyd \& De Nicolo's basic result true?

Next, once we take into account banks' (endogenous) choice of leverage, the following issues are to be addressed:

2. Does competition increase the risk of bank insolvency?

3. Does competition increase the funding liquidity risk of banks?

4. Does competition increase banks' systemic risk?

Revisiting the empirical literature through this filter leads us to regroup the empirical results in a more complete and orderly way, taking into account explicitly endogenous leverage, and refusing to consider the different measures either equivalent or complementary in the assessment of the impact of competition on financial stability.

\footnotetext{
${ }^{23}$ In the end of this section, we summarize in Table 3 the empirical papers that we surveyed, highlighting the whole variety of risk measurements studied and the diverse results obtained.

${ }^{24}$ Just like the multiple risk measures studied in the current paper, various competition measures abound in the empirical literature, ranging from franchise value (Tobin's Q), to market concentration (e.g., HHI, C-n), to structural measures (i.e., P-R H-stat., Lerner's index, Boone's indicator), and to institutions (e.g., contestability of the market such as activity and entry restrictions). (See Degryse, Kim, and Ongena (2009) for a comprehensive review on banking competition measures.) While some empirical studies, e.g., Claessens and Laeven (2004) and Schaeck, Cihák, and Wolfe (2009), show that concentration is a poor proxy for bank competition, we are still left with a wide range of possibilities, and the industrial organization literature does not provides us an unambiguous answer which measure is most reliable.
} 


\subsection{Portfolio risk: non-performing loans}

The basic postulate of the Boyd and De Nicolo (2005) is that competition will reduce the riskiness of banks' portfolio, an issue independent of the banks' leverage decision. On contrast, charter value hypothesis suggests that banks' overall investment strategy will be more risky when the opportunity cost of bankruptcy is lower. Therefore, knowing whether Boyd \& De Nicolo's basic conjecture is in line with empirical evidence is a crucial step forward. In order to measure the riskiness of assets, measures like stock volatility, as in Demsetz, Saidenberg, and Strahan (1996) and Brewer and Saidenberg (1996), are contaminated by leverage; whereas non-performing loans (NPLs) can be a natural candidate. And a bulk of literature appears to support this view by taking NPLs as one of the key dependent variables in their analysis. ${ }^{25}$

Restricting the measurement of asset risk to NPLs implies focusing on a very specific dimension of the broad link between competition and stability, where we might hope for some consensus. Unfortunately the evidence is still mixed even with this drastic reduction. The initial paper on charter value, Keeley (1990), did not consider NPLs but rather overall risk of bank failure. The use of NPLs can be found in more recent works such as Salas and Saurina (2003) and Yeyati and Micco (2007). The authors found an increase in non-performing loans as bank competition increased in Spain and in eight Latin American countries respectively. Jiménez, Lopez, and Salas (2010) also find supporting evidence for charter value hypothesis, but only if market power is measured by Lerner indices. Support for risk-shifting hypothesis can be found in Boyd and Jalal (2009), who find competition negatively correlated with loan losses for banks both in the US and in 134 non-industrialized countries. The finding is further corroborated by Berger, Klapper, and Turk-Ariss (2009). Having studied a cross-section of banks in 23 developed countries, the authors conclude that banks with a higher degree of market power exhibit significantly more loan portfolio risk.

Since market structure and bank loan loss can be jointly determined, researchers have also examined natural experiments, such as nationwide banking in the US, in order to establish a causal relationship between competition and stability. But again contradictory results arise. While Jayaratne and Strahan (1998) report that "Loan losses decrease by about 29 basis points in the short run and about 48 basis points in the longer run after statewide branching is permit-

\footnotetext{
${ }^{25}$ Some caveats are in order regarding the accuracy of this measurement. First, banks can manipulate NPLs by rolling over bad loans. Second, a risky loan granted today will only default in the future, e.g., after a two-year lag if we follow Salas and Saurina (2003), and the rate of default will depend on the business cycle (Shaffer 98).
} 
ted", Dick (2006) finds out that "charged-off losses over loans (...) appears to increase by 0.4 percentage point following deregulation". ${ }^{26}$

\subsection{Individual bank risk: insolvency}

Because of the endogeneity of banks leverage, a lower portfolio risk does not necessarily translate into a lower bank default risk. For example, Salas and Saurina (2003) show that a bank's capital ratio increases in its Tobin's Q, thus providing evidence on the (endogenous) reaction of leverage to charter value. This potential divergence is best illustrated in Berger, Klapper, and Turk-Ariss (2009): In spite of finding NPLs positively correlated with banks' market power, the authors show that banks of greater market power have lower insolvency risk because of their higher capital ratios.

Since Keeley (1990) the literature has been focusing on the risk of individual bank failure. In his classic paper, Keeley (1990) considers the market-value capital-to-asset ratio and the interest cost on large, uninsured CD's. Following his approach, Demsetz, Saidenberg, and Strahan (1996) use seven different measures of BHCs' risks and in each of them franchise value is statistically significant providing support to the charter value theory. ${ }^{27}$ Brewer and Saidenberg (1996) found also corroborating evidence that the standard deviation of stock returns volatility was negatively related to $S \& L$ franchise values as measured by the market-to-book asset ratio.

In our judgement, a bank's z-score and distance to default can be natural measurements for its insolvency risk, and many empirical works take those as the main risk measurement. ${ }^{28}$ Still, there are important nuances in the empirical findings. Beck, Jonghe, and Schepens (2011) find on average a positive relationship between banks' market power and their z-scores. Nevertheless, they report large cross-country variation in this relationship, with it being negative in many cases. Boyd and Jalal (2009) further challeged the charter value hyphothesis: using both

\footnotetext{
${ }^{26}$ The approach bears its value for banking deregulation is usually associated with a removal of barriers to entry that will increase competition. Yet, it is not only associated to the removal of barriers to entry, as it might also affect the range of financial products banks are allowed to invest in and the structure of financial institutions. In other words, bank liberalization has not only an effect on banks' competition, but also an indirect effect on banks' strategies other channels. This implies that the "banking deregulation" measure of market power explores the effect of a package of measures related to market power on financial stability, but market power is only an undistinguishable part of it.

${ }^{27}$ The risk measurements include annualized standard deviation of weekly stock returns, systematic risk, firmspecific risk, capital-to-assets Ratio, loans-to-assets ratio, commercial and industrial loans-to-assets ratio and loan portfolio concentration.

${ }^{28} \mathrm{~A}$ bank's z-score is calculated $(R o A+E / A) / \sigma(R o A)$, and is meant to capture a bank's distance from bankruptcy. Distance-to-default is defined similarly using stock market information. Note that even though theoretical models made no prediction concerning how competition affects bank leverage, empirical studies have indirectly taken into account leverage as leverage a component of the risk measures.
} 
US and cross-country samples the authors consistently find competition negatively correlated bank insolvency risk, measured by lower z-scores and actual bank failures. Confirming this view, De Nicolo and Ariss (2010) show that large loan market rents predict higher probabilities of bank failures and lower bank capitalization.

\subsection{Individual bank risk: illiquidity}

Funding liquidity risk has largely been overlooked by the empirical studies on bank competition, mainly because given a bank failure, it is very difficult to distinguish illiquidity from insolvency, Goodhart (1987). Still, recent literature suggests various indicators of bank funding liquidity risk, making it possible to examine the relationship between bank competition and funding liquidity risk.

To begin with, Brunnermeier, Gorton, and Krishnamurthy (2012) and Brunnermeier, Krishnamurthy, and Gorton (2013) suggest a liquidity mismatch index. The index is based on accounting inforamtion, ${ }^{29}$ captures funding liquidity risk from both asset and liability sides, and therefore constitutes a natural choice of liquidity risk measurement. Alternatively, based on market information, Morris and Shin (2004) identify extra yield due to illiquidity risk in their study of bond pricing; and Veronesi and Zingales (2010) construct a bank run index using CDS spreads. Both can be used too as dependent variables in a regression on bank competition. At the very least, microeconomic theories predict a range of determinents for funding liquidity risk. The risk is shown to decrease in firesale loss-absorbing buffers (e.g., higher returns or more capital), to increase in asset market liquidity (e.g., greater cash holding), and to decrease in the amount of uninsured short-term funding. As those determinants can be measured by accounting data, how they are related to banking competition invites future research. ${ }^{30}$

\subsection{Systemic risk}

The analysis of systemic risk is, obviously, even more difficult since it often has to deal with cross-country analysis, and the precise definition of a banking crisis itself as well as its timing are also subject to different interpretations. Thus, while some authors define a systemic crisis by systemwide public interventions, or $10 \%$ of the banking industry being affected, others like

\footnotetext{
${ }^{29}$ Please see Bai, Krishnamurthy, and Weymuller (2013) for its implementation.

${ }^{30}$ Based on the theoretical predictions, Morris and Shin (2009) provide a practical guide to estimate liquidity risk. And Bonfim and Kim (2011) present an attempt to measure funding liquidity risk by a variety of liquidity ratios which are constructed with the aforementioned determinants.
} 
Table 3: Does banking competition lead to instability? Various risk and competition measurements, and diverse results from the empirical literature.

\begin{tabular}{|c|c|c|c|c|}
\hline Paper & Risk & Competition & Results & Data Source \\
\hline Keeley (1990) & Interest Cost & Tobin's q & Yes & US \\
\hline Demsetz, Saidenberg, and Strahan (1996) & Stock Volatility & Market-Book Value & Yes & US \\
\hline Brewer and Saidenberg (1996) & Stock Volatility & Market-Book Value & Yes & US S\&L banks \\
\hline Jayaratne and Strahan $(1996,1998)$ & NPLs & Deregulation & No & US \\
\hline Salas and Saurina (2003) & Loan Loss & Tobin's q & Yes & Spain \\
\hline De Nicolo and Loukoianova (2005) & Z-Score & $\mathrm{HHI}$ & No & Non-industrialized \\
\hline Dick (2006) & Loan Loss & Deregulation & Yes & US \\
\hline Yeyati and Micco (2007) & Z-Score \& NPLs & P-R H-Stat. & Yes & Latin America \\
\hline Schaeck and Cihák (2010a) & Capitalization & P-R H-Stat. & No & Developed Countries \\
\hline Dell'Ariccia, Igan, and Laeven (2008) & Lending standard & Number of banks & Yes & US \\
\hline Berger, Klapper, and Turk-Ariss (2009) & Z-Score & Lerner Index/HHI & Yes & Developed Countries \\
\hline Schaeck, Cihák, and Wolfe (2009) & Crisis Dummy & P-R H-Stat. & No & Cross-Country \\
\hline Schaeck, Cihák, and Wolfe (2009) & Duration until crisis & P-R H-Stat. & No & Cross-Country \\
\hline Schaeck and Cihák (2010b) & Z-Score & Boone's Indicator & No & US/EU \\
\hline Jiménez, Lopez, and Salas (2010) & NPLs & Lerner Index & Yes & Spain \\
\hline Jiménez, Lopez, and Salas (2010) & NPLs & $\mathrm{HHI} / \mathrm{C} 5$ & No & Spain \\
\hline Beck, Jonghe, and Schepens (2011) & Z-Score & Lerner Index & Yes & Cross-Country \\
\hline De Nicolo and Ariss (2010) & Z-Score & Deposit market rent & Yes & Europe \\
\hline De Nicolo and Ariss (2010) & Z-Score & Loan market rent & No & Europe \\
\hline Dick and Lehnert (2010) & Personal bankruptcy & Deregulation & Yes & US \\
\hline
\end{tabular}

Anginer, Demirgüç-Kunt, and Zhu (2012) and De Nicolo, Bartholomew, Zaman, and Zephirin (2004) prefer to measure the probability of systemic risk by pairwise correlation of banks' distance-to-default or constructing an indicator of the probability of failure for the five largest banks. $^{31}$

Beck, Demirgüç-Kunt, and Levine (2006) analyze a sample of 69 countries over a 20-year period find that more concentrated national banking systems are subject to a lower probability of systemic banking crisis. Still, they point out that concentration need not be related to market power, as already mentioned by Claessens and Laeven (2004), and that other measures of competition may lead to the opposite result. Contradicting that result,Schaeck, Cihák, and Wolfe (2009) show, using the Panzar and Rosse H-Statistic as a measure for competition in 45 countries during 1980-2005, that more competitive banking systems are less prone to systemic crises and that time to crisis is longer in a competitive environment.

\footnotetext{
${ }^{31}$ It should be noted that with newly developed measurements on systemic risk such as marginal expected shortfalls or CoVaR in Adrian and Brunnermeier (2010), one can also link a bank's market power to its contribution to the systemic risk.
} 
Our paper's empirical prediction states here that an increase of competition may have different effects depending upon the amount of insured retail deposits, and the profitability of projects and banks' spreads, thus suggesting new lines for future empirical research based on the differentiation of different types of banking systems. It would be interesting to pursue this research by distinguishing among different types of banks. If we interpret our model literally, this would be to distinguish banks with low deposit to asset ratios from those with a high deposit to asset ratio. Still, more generally, this could be interpreted as dividing the banks according to their different access to short maturity market funds.

\section{Discussion and policy implications}

Because the aim of our paper is to clarify the multiple concepts of risk and the key role leverage, our model has made a number of drastic simplifying assumptions that although lead to relatively simple propositions but cannot be easily generalized. Indeed, our framework considerably understates the complexity of the issue, because competition also affects banks' portfolio choice, e.g., the correlation of their portfolios, securitization, cash hoarding, and so on, which are all abstracted from in the current setup.

Also our model's main objective is not to address the design of overall banking regulation, and consequently, from that perspective, it suffers from two limitations: On the one hand, it does not take into account the impact of competition on increasing productivity through the Shumpeterian creative destruction process, Dick (2006). On the other hand, it does not consider the supply of credit, which is exogenously set as all firms are able to get financed. In spite of this, it is interesting to consider the implications that our results have for regulatory policies. Two main lessons can be drawn: the first regarding the impact of competition in general, and the second regarding capital and liquidity regulation.

The first lesson is that a one-size-fits-all approach to the analysis of the link between banking competition and financial stability is insufficiently rigorous. To be more precise, we conclude that the link depends among other things on the degree of market power of financial institutions. If financial institutions have a high market power, then competition reduces total bankruptcy risk (the sum of insolvency and liquidity risk) in financial institutions, confirming the risk shifting hypothesis of Boyd and De Nicoló. Still, in this high market power case, we show that the impact is dampened by the increase in liquidity risk the increase in competition 
causes. On the other hand, once the banking industry is sufficiently competitive, the inequality is reversed and additional competition leads to financial instability, thus confirming the charter value assumption. From that perspective the policy position depends upon whether market power is above or below some threshold that depends upon firms' productivity as well as upon banks' liability structure.

Second, a simple extension of our framework, consisting in distinguishing wholesale shortterm market funding from long-term market funding $\left(D=D_{S}+D_{L}\right)$, also has implications regarding liquidity regulation. Indeed, we show that a more competitive banking industry has a higher level of liquidity risk, proportional to $D_{S}$, if leverage is exogenous. This is directly related to capital regulation, because if capital regulation is binding, leverage becomes exogenous. As a consequence, liquidity regulation, as suggested by Basel III, can reduce the liquidity risk that is implied by fiercer competition.

\section{Concluding remarks}

We develop a model to study bank risk in competitive environments. We model explicitly the credit risk created by borrowing firms' moral hazard and examine how banks optimally adjust their leverage in the light of various risk. With the theoretical framework, we clarify the concept of financial stability: it has multiple dimensions ranging from portfolio risk to systemic risk. We show that competition can affect different types of risk differently, and the idea of an identical impact of banking competition on financial stability that would hold across types of banks and types of firms has no theoretical foundation. This can help explain the diverse findings in the empirical literature. We further suggest that banks' leverage and liability structure play a key role in determining the relationship between banking competition and financial stability. As a consequence, testing our model's prediction that the competition-financial stability link depends upon the type of bank and the state of the economy through firms self financing and productivity may lead to an important step forward in our understanding of the issue. 


\section{Appendix A Proof of propositions}

\section{Appendix A.1 Proof of lemma 1}

To derive the uniform distribution of loan loss $\gamma$, take a risky type $\tilde{b}<1 /(x-r)$; and define the fraction of entrepreneurs below $\tilde{b}$ in the risky pool by $\tilde{\gamma}$. We have

$$
\tilde{\gamma}=\frac{\tilde{b}-0}{1 /(x-r)-0}=\tilde{b}(x-r) \text {. }
$$

Consider the critical realization $\tilde{z}=\Phi^{-1}\left(1-P_{\tilde{b}}^{*}\right)$ such that an entrepreneur of $\tilde{b}$ does not default but all types $b<\tilde{b}$ do. So for $z=\hat{z}$, one will have $\gamma=\tilde{\gamma}$. To derive the distribution of $\gamma$, notice that

$$
\begin{aligned}
F(\tilde{\gamma}) & \equiv \operatorname{Prob}(\gamma<\tilde{\gamma})=\operatorname{Prob}(z>\tilde{z})=1-\operatorname{Prob}(z<\tilde{z}) \\
& =1-\Phi\left(\Phi^{-1}\left(1-P_{\tilde{b}}^{*}\right)\right)=P_{\tilde{b}}^{*} \\
& =\tilde{b}(x-r) .
\end{aligned}
$$

By equation (A.20), we have $\tilde{b}=\tilde{\gamma} /(x-r)$. Substitution yields

$$
F(\tilde{\gamma})=\tilde{\gamma}
$$

implying $\gamma \sim U(0,1)$.

\section{Appendix A.2 Proof of proposition 1}

On the comparative statics of insolvency risk, computation is simplified if we consider its complementary probability, $1-\rho_{S R}=[r-(F+D)] /(1-\alpha) r$. Examining its first order derivative with respect to $r$, we obtain:

$$
\begin{aligned}
\frac{\partial\left(1-\rho_{S R}\right)}{\partial r} & =\frac{1}{(1-\alpha)^{2} r^{2}}\left[(1-\alpha) r-\frac{\partial[(1-\alpha) r]}{\partial r}[r-(F+D)]\right] \\
& =\frac{1}{(1-\alpha)^{2} r^{2}}\left[(1-\alpha) r-\left[(1-\alpha)-\frac{\partial \alpha}{\partial r} r\right][r-(F+D)]\right] \\
& =\frac{1}{(1-\alpha)^{2} r^{2}}\left[\frac{\partial \alpha}{\partial r} r^{2}+\left[(1-\alpha)-\frac{\partial \alpha}{\partial r} r\right](F+D)\right] .
\end{aligned}
$$


Recall that $\partial \alpha / \partial r=-1 / B(x-r)^{2}$ and $(1-\alpha)=1 / B(x-r)$. Taking out the common factor, we will have

$$
\begin{aligned}
\frac{\partial\left(1-\rho_{S R}\right)}{\partial r} & =\frac{1}{(1-\alpha)^{2} r^{2}} \frac{\partial \alpha}{\partial r}\left[r^{2}+[-(x-r)-r](F+D)\right] \\
& =\frac{1}{(1-\alpha)^{2} r^{2}} \frac{\partial \alpha}{\partial r}\left[r^{2}-x(F+D)\right]
\end{aligned}
$$

Therefore,

$$
\frac{\partial \rho_{S R}}{\partial r}=\frac{-1}{(1-\alpha)^{2} r^{2}} \frac{\partial \alpha}{\partial r}\left[r^{2}-x(F+D)\right] .
$$

Pure insolvency risk is reduced by competition if and only if

$$
r^{2}>x(F+D)
$$

\section{Appendix A.3 Proof of proposition 4}

A systemic crisis takes place if both banks' cash flow fall below $\theta^{* *}$, i.e., $\rho_{S Y S}=\operatorname{Prob}(\theta<$ $\left.\theta^{* *}\right)^{2}$. This allows us to obtain:

$$
\begin{aligned}
\frac{\partial \rho_{S Y S}}{\partial r} & =2 \operatorname{Prob}\left(\theta<\theta^{* *}\right) \frac{\partial}{\partial r} \operatorname{Prob}\left(\theta<\theta^{* *}\right) \\
& =2 \operatorname{Prob}\left(\theta<\theta^{* *}\right) \frac{\partial}{\partial r}\left(1-\frac{r-\theta^{* *}}{(1-\alpha) r}\right) \\
& =2 \operatorname{Prob}\left(\theta<\theta^{* *}\right) \frac{-1}{(1-\alpha)^{2} r^{2}}\left[(1-\alpha) r-\left[(1-\alpha)-\frac{\partial \alpha}{\partial r} r\right]\left(r-\theta^{* *}\right)\right] \\
& =2 \operatorname{Prob}\left(\theta<\theta^{* *}\right) \frac{-1}{(1-\alpha)^{2} r^{2}} \frac{\partial \alpha}{\partial r}\left[r^{2}-x \theta^{* *}\right] \\
& =2 \operatorname{Prob}\left(\theta<\theta^{* *}\right) \frac{-1}{(1-\alpha)^{2} r^{2}} \frac{\partial \alpha}{\partial r}\left[r^{2}-x\left(F+\mu^{\prime} D\right)\right] .
\end{aligned}
$$

As $\partial \alpha / \partial r<0$, the sign of the comparative statics is determined by $r^{2}-x\left(F+\mu^{\prime} D\right)$ : the risk of a systemic crisis decreases with competition if and only if $r^{2}>x\left(F+\mu^{\prime} D\right)$.

\section{Appendix A.4 Proof of proposition 6}

Denote $c \equiv 1 /\left(\mu^{2} / k+2 \mu\right)$. The pure insolvency risk, illiquidity risk, and total credit risk can be written as the following, with again total credit risk being the summation of pure insolvency 
risk and illiquidity risk. The comparative statics with respect to $r$ follow from the definitions.

$$
\begin{aligned}
\rho_{S R}^{*} & \equiv 1-\frac{r-F-D^{*}}{(1-\alpha) r}=1-\frac{(1-c)(r-F)}{(1-\alpha) r} \\
\rho_{I L}^{*} & \equiv(\mu-1) \frac{D^{*}}{(1-\alpha) r}=\frac{c(\mu-1)(r-F)}{(1-\alpha) r} \\
\rho_{T C R}^{*} & \equiv 1-\frac{r-F-\mu D^{*}}{(1-\alpha) r}=1-\frac{(1-\mu c)(r-F)}{(1-\alpha) r}
\end{aligned}
$$

(1) Comparative statics: Insolvency risk

$$
\frac{\partial \rho_{S R}^{*}}{\partial r}=-(1-c) \frac{\partial}{\partial r}\left(\frac{r-F}{(1-\alpha) r}\right)
$$

We have shown $c<1$. So the expression shares the same sign as

$$
\frac{\partial}{\partial r}\left(\frac{r-F}{(1-\alpha) r}\right)
$$

(2) Comparative statics: Liquidity risk

$$
\frac{\partial \rho_{I L}^{*}}{\partial r}=(\mu-1) c \frac{\partial}{\partial r}\left(\frac{r-F}{(1-\alpha) r}\right)
$$

With $\mu>1$, the sign will be opposite to that of expression (A.22).

(3) Comparative statics: Total credit risk

$$
\frac{\partial \rho_{T C R}^{*}}{\partial r}=-(1-\mu c) \frac{\partial}{\partial r}\left(\frac{r-F}{(1-\alpha) r}\right)
$$

Note that $\mu c=1 /(\mu / k+2)<1$. The comparative statics of total credit risk is again determined by the sign of expression (A.22).

Therefore when competitive environment changes, pure insolvency risk moves in the opposite direction as pure liquidity risk. With the latter dominating, total credit risk changes in the 
same direction as that of pure insolvency. Now we characterize the condition that

$$
\begin{aligned}
\frac{\partial}{\partial r}\left(\frac{r-F}{(1-\alpha) r}\right) & =\frac{1}{(1-\alpha)^{2} r^{2}}\left[(1-\alpha) r-\left[-\frac{\partial \alpha}{\partial r} r+(1-\alpha)\right](r-F)\right] \\
& =\frac{1}{(1-\alpha)^{2} r^{2}}\left[\frac{\partial \alpha}{\partial r} r^{2}+\left[-\frac{\partial \alpha}{\partial r} r+(1-\alpha)\right] F\right] \\
& =\frac{1}{(1-\alpha)^{2} r^{2}} \frac{\partial \alpha}{\partial r}\left[r^{2}-r F-(x-r) F\right] \\
& =\frac{1}{(1-\alpha)^{2} r^{2}} \frac{\partial \alpha}{\partial r}\left(r^{2}-x F\right) .
\end{aligned}
$$

With $\partial \alpha / \partial r<0$, competition increases insolvency risk, decreases liquidity risk, and increases total credit risk if and only if

$$
r^{2}>x F
$$

\section{Appendix A.5 Proof of proposition 7}

The proof resembles that of proposition 6. Comparative statics again hinge on the sign of

$$
\frac{\partial}{\partial r}\left(\frac{r-F}{(1-\alpha) r}\right)
$$

Note that for the exposure to contagion

$$
\frac{\partial \rho_{C T G}^{*}}{\partial r}=\left(\mu^{\prime}-\mu\right) \frac{\partial}{\partial r}\left(\frac{D^{*}}{(1-\alpha) r}\right)=\left(\mu^{\prime}-\mu\right) c \frac{\partial}{\partial r}\left(\frac{r-F}{(1-\alpha) r}\right)
$$

and for the risk of a systemic crisis

$$
\begin{aligned}
\frac{\partial \rho_{S Y S}^{*}}{\partial r} & =2 \operatorname{Prob}\left(\theta<\theta^{* *}\right) \frac{\partial}{\partial r} \operatorname{Prob}\left(\theta<\theta^{* *}\right) \\
& =2 \operatorname{Prob}\left(\theta<\theta^{* *}\right) \frac{\partial}{\partial r}\left(1-\frac{r-F-\mu^{\prime} D^{*}}{(1-\alpha) r}\right) \\
& =-2 \operatorname{Prob}\left(\theta<\theta^{* *}\right)\left(1-\mu^{\prime} c\right) \frac{\partial}{\partial r}\left(\frac{r-F}{(1-\alpha) r}\right) .
\end{aligned}
$$

Therefore, when $r^{2}>x F$, loan competition leads to greater exposure to contagion yet a smaller chance of systemic crisis. 


\section{Appendix B The Laplacian property}

In the model, the noisy signal received by representative creditor $i$ has a structure

$$
s_{i}=\theta+\epsilon_{i}
$$

We assume $\epsilon_{i}$ follows a continuous distribution with c.d.f. $G$.

Denote the critical signal for creditor $i$ to switch from "wait" to "run" by $s^{*}$. And upon observing $s^{*}$, the creditor $i$ believes a $M$ fraction of creditors observing signals higher than hers. We prove $M \sim U(0,1)$.

Proof. For the continuous distribution $G$, the fraction of creditors who observes signal higher than $s^{*}$ equals the probability that a creditor $j$ 's signal $s_{j}>s^{*}$. Then, we have

$$
\begin{aligned}
M & =\operatorname{Prob}\left(s_{j}>s^{*} \mid s_{i}=s^{*}\right)=\operatorname{Prob}\left(\theta+\epsilon_{j}>s^{*} \mid s_{i}=s^{*}\right) \\
& =\operatorname{Prob}\left(\epsilon_{j}>s^{*}-\theta \mid s_{i}=s^{*}\right) \\
& =1-G\left(s^{*}-\theta\right)
\end{aligned}
$$

The randomness of $M$ is rooted in the fact that by observing $s_{i}=s^{*}$, creditor $i$ is uncertain about the realization of $\theta$. As the perceived value of $\theta$ is random, so is the perceived $M$. Now we derive the distribution function of $M$. For $\hat{M} \in[0,1]$, we have

$$
\begin{aligned}
\operatorname{Prob}\left(M<\hat{M} \mid s_{i}=s^{*}\right) & =\operatorname{Prob}\left(1-G\left(s^{*}-\theta\right)<\hat{M} \mid s_{i}=s^{*}\right) \\
& =\operatorname{Prob}\left(\theta<s^{*}-G^{-1}(1-\hat{M}) \mid s_{i}=s^{*}\right) \\
& =\operatorname{Prob}\left(s^{*}-\epsilon_{j}<s^{*}-G^{-1}(1-\hat{M}) \mid s_{i}=s^{*}\right) \\
& =\operatorname{Prob}\left(\epsilon_{j}>G^{-1}(1-\hat{M}) \mid s_{i}=s^{*}\right) \\
& =1-G\left(G^{-1}(1-\hat{M})\right) \\
& =\hat{M}
\end{aligned}
$$

Note that $M=1-G\left(s^{*}-\theta\right) \in[0,1]$. Therefore for $\hat{M}<0, \operatorname{Prob}(M<\hat{M})=0$; and for $\hat{M}>1$, $\operatorname{Prob}(M<\hat{M})=1$. We prove $M$ follows a uniform distribution on [0,1]. 


\section{References}

Adrian, T., and M. K. Brunnermeier (2010): “CoVaR,” Discussion paper, Federal Reserve Bank of New York.

Allen, F., E. Carletti, and R. Marquez (2009): “Credit Market Competition and Capital Regulation," Review of Financial Studies, 24(4).

Anginer, D., A. Demirgüç-Kunt, and M. Zhu (2012): “How Does Bank Competition Affect Systemic Stability?," SSRN eLibrary.

Bai, J., A. Krishnamurthy, and C.-H. Weymuller (2013): "Measuring Liquidity Mismatch in the Banking Sector," SSRN Scholarly Paper ID 2343043, Social Science Research Network, Rochester, NY.

Beck, T., A. Demirgüç-Kunt, and R. Levine (2006): "Bank concentration, competition, and crises: First results," Journal of Banking E Finance, 30(5), 1581-1603.

Beck, T., O. D. Jonghe, and G. Schepens (2011): "Bank Competition and Stability: CrossCountry Heterogeneity," Discussion paper.

Berger, A., L. Klapper, and R. Turk-Ariss (2009): "Bank Competition and Financial Stability," Journal of Financial Services Research, 35(2), 99-118.

BonfiM, D., AND M. Kim (2011): “Liquidity risk in banking: is there herding?," Retrieved on December 14th.

Boyd, John H, D. N. G., And A. M. Jalal (2009): "Bank Competition, Risk and Asset Allocations," SSRN eLibrary.

Boyd, J. H., and G. De Nicolo (2005): “The Theory of Bank Risk Taking and Competition Revisited," The Journal of Finance, 60(3), 1329-1343.

Boyd, J. H., G. De Nicolo, and E. Loukoianova (2009): "Banking Crises and Crisis Dating: Theory and Evidence," SSRN eLibrary.

Brewer, E., And M. R. SAIDEnberg (1996): "Franchise value, ownership structure, and risk at savings institutions," Research Paper 9632, Federal Reserve Bank of New York. 
Broecker, T. (1990): "Credit-Worthiness Tests and Interbank Competition," Econometrica, 58(2), 429-452.

Brunnermeier, M., A. Krishnamurthy, and G. Gorton (2013): "Liquidity mismatch measurement," in Risk Topography: Systemic Risk and Macro Modeling. University of Chicago Press.

Brunnermeier, M. K., G. Gorton, and A. Krishnamurthy (2012): “Risk Topography,” NBER Macroeconomics Annual, 26(1), 149-176.

Carlsson, H., and E. Van Damme (1993): “Global Games and Equilibrium Selection,” Econometrica, 61(5), 989-1018.

Claessens, S., and L. Laeven (2004): "What Drives Bank Competition? Some International Evidence," Journal of Money, Credit and Banking, 36(3), 563-583.

De Nicolo, G., and R. T. Ariss (2010): "Bank Market Power Rents and Risk: Theory and Measurement," Discussion paper.

De Nicolo, G., P. Bartholomew, J. Zaman, and M. Zephirin (2004): “Bank Consolidation, Internationalization, and Conglomeration: Trends and Implications for Financial Risk," Financial Markets, Institutions $\mathcal{E}$ Instruments, 13(4), 173-217.

De Nicolo, G., and E. Loukoianova (2005): "Bank Ownership, Market Structure and Risk," IMF Working Papers.

Degryse, H., M. Kim, and S. Ongena (2009): Microeconometrics of Banking: Methods, Applications, and Results. Oxford University Press, USA, first edition edn.

Dell'Ariccia, G., D. Igan, and L. Laeven (2008): “Credit Booms and Lending Standards: Evidence from the Subprime Mortgage Market," SSRN eLibrary.

Demsetz, R. S., M. R. Saidenberg, and P. E. Strahan (1996): "Banks with something to lose: the disciplinary role of franchise value," Economic Policy Review, (Oct), 1-14.

Diamond, D. W., and R. G. Rajan (2000): “A Theory of Bank Capital,” The Journal of Finance, 55(6), 2431-2465.

Dick, A. (2006): "Nationwide Branching and Its Impact on Market Structure, Quality, and Bank Performance," The Journal of Business, 79(2), 567-592. 
Dick, A. A., AND A. Lehnert (2010): "Personal Bankruptcy and Credit Market Competition," The Journal of Finance, 65(2), 655-686.

Goldstein, I., and A. Pauzner (2005): "Demand-Deposit Contracts and the Probability of Bank Runs," The Journal of Finance, 60(3), 1293-1327.

Goodhart, C. A. E. (1987): "Why Do Banks Need a Central Bank?," Oxford Economic Papers, 39(1), 75-89.

Jayaratne, J., and P. E. Strahan (1996): “The Finance-Growth Nexus: Evidence from Bank Branch Deregulation,” The Quarterly Journal of Economics, 111(3), 639-670.

(1998): "Entry Restrictions, Industry Evolution, and Dynamic Efficiency: Evidence from Commercial Banking," Journal of Law E Economics, 41, 239.

JimÉnez, G., J. A. Lopez, and J. S. Salas (2010): "How Does Competition Impact Bank RiskTaking?," SSRN eLibrary.

Keeley, M. C. (1990): “Deposit Insurance, Risk, and Market Power in Banking,” The American Economic Review, 80(5), 1183-1200.

Martinez-Miera, D., and R. Repullo (2010): "Does Competition Reduce the Risk of Bank Failure?," Review of Financial Studies, 23(10), 3638 -3664.

Morris, S., AND H. S. SHIN (2000): "Rethinking Multiple Equilibria in Macroeconomic Modeling," NBER Macroeconomics Annual, 15, 139-161.

_ (2001): “Global Games: Theory and Applications," SSRN eLibrary. (2004): “Coordination risk and the price of debt," European Economic Review, 48(1), 133-153.

Morris, S., AND H. S. SHIN (2009): “Illiquidity component of credit risk,” Princeton University manuscript.

Myers, S. C., and N. S. Majluf (1984): “Corporate financing and investment decisions when firms have information that investors do not have," Journal of Financial Economics, 13(2), 187-221. 
Rochet, J., AND X. Vives (2004): “Coordination Failures and the Lender of Last Resort: Was Bagehot Right After All?," Journal of the European Economic Association, 2(6), 1116-1147.

Salas, V., and J. Saurina (2003): "Deregulation, market power and risk behaviour in Spanish banks," European Economic Review, 47(6), 1061-1075.

Schaeck, K., And M. CiнÁk (2010a): "Banking Competition and Capital Ratios," European Financial Management.

(2010b): “Competition, Efficiency, and Soundness in Banking: An Industrial Organization Perspective," SSRN eLibrary.

Schaeck, K., M. Cihák, and S. Wolfe (2009): “Are Competitive Banking Systems More Stable?," Journal of Money, Credit and Banking, 41(4), 711-734.

VasiceK, O. (2002): “The distribution of loan portfolio value,” Risk, 15(12), 160-162.

Veronesi, P., and L. Zingales (2010): “Paulson's gift,” Journal of Financial Economics, 97(3), $339-368$.

Wagner, W. (2009): “Loan Market Competition and Bank Risk-Taking,” Journal of Financial Services Research, 37(1), 71-81.

Yeyati, E. L., AND A. Micco (2007): "Concentration and foreign penetration in Latin American banking sectors: Impact on competition and risk," Journal of Banking $\mathcal{E}$ Finance, 31(6), $1633-1647$. 